\title{
Endometriosis-associated Clear Cell Carcinoma of the Abdominal Wall After Caesarean Section: A Case Report and Review of the Literature
}

\author{
LUCA GIANNELLA $^{1}$, MATTEO SERRI $^{1}$, ELENA MACCARONI ${ }^{2}$, \\ JACOPO DI GIUSEPPE ${ }^{1}$, GIOVANNI DELLI CARPINI ${ }^{1}$, ROSSANA BERARDI ${ }^{2}$, \\ FRANCESCO SOPRACORDEVOLE ${ }^{3}$ and ANDREA CIAVATTINI ${ }^{1}$
}

${ }^{I}$ Woman's Health Sciences Department, Gynecologic Section, Polytechnic University of Marche, Ancona, Italy;

${ }^{2}$ Medical Oncology Unit, Polytechnic University of Marche, Azienda Ospedaliero-Universitaria Ospedali Riuniti Umberto I, GM Lancisi, G Salesi, Ancona, Italy; ${ }^{3}$ Gynecological Oncology Unit, CRO Centro di Riferimento Oncologico National Cancer Institute, Aviano, Italy

\begin{abstract}
Background/Aim: Clear cell carcinoma of the abdominal wall is a sporadic event. To date, about thirty cases have been reported in the literature. This article provides a case report and literature review of an infrequent occurrence with poor prognosis. Case Report: A 45-year-old woman with pelvic pain and an abdominal mass came to our attention. Her medical history was notable for two previous cesarean sections. Physical examination revealed a smooth, multilocular mass measuring about $20 \mathrm{~cm}$, arising from the previous surgical scar. Histology revealed clear-cell carcinoma resulting from the transformation of abdominal wall endometriosis. Given the disease extent, the patient underwent front-line chemotherapy. After several and multiple chemotherapy regimens, there was a disease progression that resulted in the death of the patient in 7 months. The literature review showed that a previous cesarean section was present in $91 \%$ of cases. Besides, approximately $26.5 \%$ of women died within 12 months of being diagnosed. The mean age of women was 45.88 years, while the average size of the lesion was $11 \mathrm{~cm}$. Conclusion: Clear cell carcinoma is a rare but occurring event. Middleaged women showing an abdominal wall mass in close relation with a surgical scar from a previous cesarean
\end{abstract}

This article is freely accessible online.

Correspondence to: Andrea Ciavattini, MD, Woman's Health Sciences Department, Gynecologic Section, Polytechnic University of Marche, Via F. Corridoni 11, 60123 Ancona, Italy. Tel: +39 07136745, Fax: +39 07136575, e-mail: ciavattini.a@libero.it

Key Words: Clear cell carcinoma, abdominal wall endometriosis, cesarean scar endometriosis, endometriosis, surgery, chemotherapy. section must be promptly investigated. Treatment options usually include surgery and chemotherapy with poor results.

Endometriosis is defined as an inflammatory disease characterized by the presence of a functioning endometrial gland and stroma outside the uterus (1). These lesions usually involve the ovaries and, more rarely, bowel, ureters, lung, and abdominal wall (1). In women with abdominal wall endometriosis (AWE), a prior history of gynecological surgery with the opening of the uterine cavity is usually found. In this regard, scar endometriosis can be explained by iatrogenic transplantation of endometrial tissue to the wound edge during the surgical procedure $(2,3)$.

The incidence of abdominal surgical scar endometriosis ranges between $0.03 \%$ and $1.08 \%$ of women undergoing pelvic surgery $(4,5)$. It is often misdiagnosed and detected preoperatively in $20 \%-50 \%$ of cases (2). Women typically report a cyclic menstrual pain referred to the abdominal wall. The differential diagnosis of a subcutaneous mass associated with a previous surgical incision of the abdominal wall includes abscess, hematoma, hernia, desmoid tumor, sarcoma, and metastatic disease (6). An accurate medical history and physical examination can guide towards diagnosis. Definitive treatment includes wide local excision with free margins. Hormonal therapies relieve symptoms but do not prevent recurrences (6).

Although endometriosis is considered a benign condition, malignant transformation is rare but possible. About $80 \%$ of endometriosis-associated malignancies have been found in the ovary, whereas $20 \%$ are localized in extra-gonadal sites (7). Clear cell histology represents $4.5 \%$ of the extra-pelvic endometriosis-associated malignancies. It represents the most common histotype in the case of abdominal wall localization (8). 

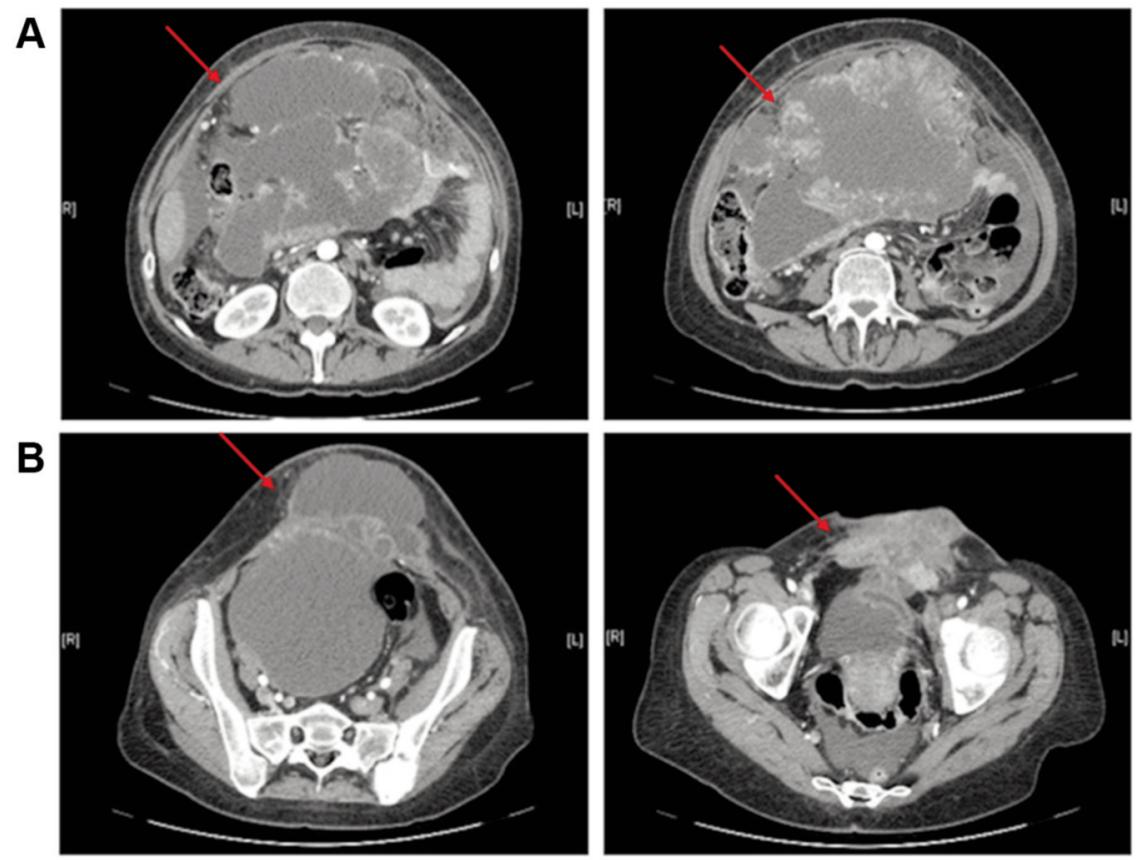

Figure 1. Computed tomography scan showing intra-abdominal (A), and parietal (B) disease extension after second-line chemotherapy (red arrow).

Published literature on this topic is weak. Here we report the case of a patient presenting with clear cell carcinoma (CCC) of the abdominal wall at the site of the previous cesarean section scar. Furthermore, we included a review of the literature regarding this unusual occurrence.

\section{Case Report}

A 45-year-old woman came to our attention for pelvic pain and an abdominal mass present for three months. She noticed a remarkable dimensional increase of the mass in the last two weeks. Her personal history showed two previous Caesarean sections, 22 and 13 years before. No other relevant medical problems were reported. She complained of intense dysmenorrhea on the first day of menstruation, along with pain in the abdominal wall and deep in the uterine scar of cesarean section. She had no family history of gynecological malignancies and had never taken hormone therapy.

Physical examination revealed a smooth, multilocular mass measuring about $20 \mathrm{~cm}$, arising from the middle-left side of the cesarean scar to the umbilical region. Abdominopelvic magnetic resonance imaging (MRI) and computed tomography (CT) scan revealed the presence of an anterior abdominal wall mass showing solid and lacunar areas with a diameter of $18 \mathrm{~cm}$, infiltrating bladder wall and multiple iliac lymph nodes. A metastatic pararectal mass of $8.5 \mathrm{~cm}$, multiple liver nodules, and bilateral pulmonary metastases were also found. Uterus and adnexa appeared disease-free.
An ultrasound-guided fine-needle aspiration biopsy and coreneedle biopsy were performed. Histopathological examination revealed CCC cells deriving from gynecological cancer, suggesting a malignant transformation of AWE.

Given the disease extent, the patient underwent front-line chemotherapy with carboplatin $(\mathrm{AUC}=2)$ and paclitaxel $(80$ $\mathrm{mg} / \mathrm{m}^{2}$ ) weekly. Two months after the first-line chemotherapy, a new MRI documented partial regression of lung metastases, but also revealed an increase of the anterior abdominal wall mass. Furthermore, pelvic skeletal metastases were revealed. Because of bone lesions, the patient had significant pelvic pain requiring external beam radiation therapy (single dose of $800 \mathrm{cGy}$ ) at the level of iliac bone metastasis.

Due to progressive disease, second-line chemotherapy with gemcitabine was administered $\left(1000 \mathrm{mg} / \mathrm{m}^{2}\right.$ days $1-8$ weekly). After three cycles of gemcitabine, a thoracic/abdominal CT scan revealed a significant progression of abdominopelvic masses $(26 \mathrm{~cm}$ maximum diameter) and a slight regression of pulmonary metastasis. Figure 1 shows a CT scan revealing a wide intra-abdominal and parietal extension of the lesion. Third-line chemotherapy with Pegylated liposomal doxorubicin $40 \mathrm{mg} / \mathrm{m}^{2}$ every 28 days was started. Still, after three weeks from the first administration, the patient was hospitalized in the Internal Medicine Clinic due to severe cachexia. The patient received palliative care and died a few days later, exactly 7 months after the cancer diagnosis. 
Table I. Summary of cases of clear cell carcinomas arising from abdominal wall scar.

\begin{tabular}{|c|c|c|c|c|c|c|}
\hline References & Age & Size $(\mathrm{cm})$ & Treatment & Histology & Previous surgery & Follow-up \\
\hline Schnieber, 1986 (14) & 40 & - & Surgery+RT & $\mathrm{CCC}+\mathrm{endometriosis}$ & $1 \mathrm{CS}$ & Death after 18 months \\
\hline Hitti, 1996 (15) & 46 & 6 & Surgery $+\mathrm{CT}+\mathrm{RT}$ & $\mathrm{CCC}+\mathrm{endometriosis}$ & $1 \mathrm{CS}$ & No relapse after 30 months \\
\hline Miller, 1998 (16) & 38 & 4 & Surgery $+\mathrm{CT}+\mathrm{RT}$ & $\mathrm{CCC}$ & $1 \mathrm{CS}$ & No relapse after 60 months \\
\hline Park, 1999 (17) & 56 & 5 & Surgery+CT & $\mathrm{CCC}+$ endometriosis & $1 \mathrm{CS}$ & - \\
\hline Ishida, 2003 (18) & 56 & 10 & Surgery+CT & $\mathrm{CCC}$ & $1 \mathrm{CS}$ & Death after 24 months \\
\hline Sergent, 2006 (19) & 45 & 20 & Surgery & $\mathrm{CCC}+$ endometriosis & $2 \mathrm{CS}$ & Death after 6 months \\
\hline Alberto, 2006 (20) & 38 & 6 & Surgery $+\mathrm{CT}+\mathrm{RT}$ & $\mathrm{CCC}$ & $1 \mathrm{CS}$ & - \\
\hline Razzouk, 2007 (21) & 46 & $>20$ & Surgery+CT & $\mathrm{CCC}+\mathrm{endometriosis}$ & $2 \mathrm{CS}$ & Death after 6 months \\
\hline Harry, 2007 (22) & 55 & 4 & Surgery+RT & $\mathrm{CCC}+$ endometriosis & $\begin{array}{l}\text { Open tubal } \\
\text { sterilization }\end{array}$ & No relapse after 18 months \\
\hline Rust, 2008 (23) & 42 & 5 & Surgery & $\mathrm{CCC}+$ endometriosis & $\begin{array}{l}\text { Total abdominal } \\
\text { hysterectomy }\end{array}$ & - \\
\hline Bats, 2008 (6) & 38 & 10 & $\mathrm{CT}+$ Surgery & $\mathrm{CCC}+$ endometriosis & $1 \mathrm{CS}$ & Relapse after 4 months \\
\hline Achach, 2008 (24) & 49 & 9 & Surgery+CT & $\mathrm{CCC}$ & Open myomectomy & Relapse after 6 months \\
\hline Williams, 2009 (25) & 53 & 25 & Surgery+CT & $\mathrm{CCC}$ & $1 \mathrm{CS}$ & Death after 11 months \\
\hline Matsuo, 2009 (26) & 37 & 14 & Surgery+CT & $\mathrm{CCC}+$ endometriosis & $\begin{array}{l}\text { Laparotomy for } \\
\text { endometriosis }\end{array}$ & - \\
\hline Bourdel, 2010 (27) & 43 & 9 & Surgery+CT+RT & $\mathrm{CCC}+$ endometriosis & $2 \mathrm{CS}$ & Death after 22 months \\
\hline Yan, 2011 (28) & 41 & 9 & Surgery+CT & $\mathrm{CCC}$ & $2 \mathrm{CS}$ & No relapse after 24 months \\
\hline Li, 2012 (39) & 49 & 9 & Surgery+CT & $\mathrm{CCC}$ & $1 \mathrm{CS}$ & No relapse after 8 months \\
\hline Mert, 2012 (30) & 42 & 15 & $\mathrm{CT}+$ Surgery & $\mathrm{CCC}+\mathrm{endometriosis}$ & $2 \mathrm{CS}+$ tubal ligation & No relapse after 1 month \\
\hline Mert, 2012 (30) & 51 & 6 & Surgery+RT & - & 2 CS+hysterectomy & No relapse after 31 months \\
\hline Shalin, 2012 (31) & 47 & 3 & Surgery $+\mathrm{CT}+\mathrm{RT}$ & $\mathrm{CCC}+$ endometriosis & $1 \mathrm{CS}$ & Relapse after 5 months \\
\hline Ijichi, 2014 (32) & 60 & 4 & Surgery & $\mathrm{CCC}+$ endometriosis & $1 \mathrm{CS}$ & Relapse after 8 months \\
\hline Aust, 2015 (33) & 47 & 10 & Surgery+CT & $\mathrm{CCC}$ & $1 \mathrm{CS}$ & No relapse after 10 months \\
\hline Heller, 2014 (34) & 37 & 18 & Surgery & $\mathrm{CCC}$ & $3 \mathrm{CS}$ & Relapse after 5 months \\
\hline Liu, 2014 (35) & 39 & 6 & Surgery+CT & $\mathrm{CCC}+$ endometriosis & $1 \mathrm{CS}$ & Death after 12 months \\
\hline Ruiz, 2015 (36) & 41 & 15 & Surgery $+\mathrm{CT}+\mathrm{RT}$ & $\mathrm{CCC}+\mathrm{endometriosis}$ & $1 \mathrm{CS}$ & Relapse after 6 months \\
\hline Ruiz, 2015 (36) & 57 & 19 & Surgery $+\mathrm{CT}+\mathrm{RT}$ & $\mathrm{CCC}+$ endometriosis & $3 \mathrm{CS}$ & $\begin{array}{c}\text { No relapse after } 6 \text { cycles of } \\
\text { chemotherapy }\end{array}$ \\
\hline Sosa-Duràn, 2015 (37) & 45 & 9 & Surgery & $\mathrm{CCC}+$ endometriosis & $3 \mathrm{CS}$ & No relapse after 16 months \\
\hline Ferrandina, 2016 (10) & 44 & 22 & $\mathrm{CT}+$ Surgery & $\mathrm{CCC}+$ endometriosis & $1 \mathrm{CS}$ & Death after 6 months \\
\hline Graur, 2017 (38) & - & - & Surgery & $\mathrm{CCC}$ & $1 \mathrm{CS}$ & - \\
\hline Marques, 2017 (39) & 47 & 11 & 2 Surgeries+CT & $\mathrm{CCC}+$ endometriosis & $3 \mathrm{CS}$ & No relapse after 45 months \\
\hline Gentile, 2018 (40) & 42 & 10 & Surgery+CT & $\mathrm{CCC}+$ endometriosis & $1 \mathrm{CS}$ & No relapse after 8 months \\
\hline Rivera Rolon, 2019 (41) & 48 & 7 & Surgery+CT & $\mathrm{CCC}$ & 3 CS+hysterectomy & - \\
\hline Lopes, 2019 (42) & 48 & 12 & Surgery+CT & $\mathrm{CCC}+$ endometriosis & $1 \mathrm{CS}$ & $\begin{array}{c}\text { No relapse after } 4 \text { cycles of } \\
\text { chemotherapy }\end{array}$ \\
\hline Behbehani, 2019 (43) & 48 & 7 & Surgery+CT & $\mathrm{CCC}+$ endometriosis & $\begin{array}{c}1 \mathrm{CS}+\text { supra-cervical } \\
\text { hysterectomy }\end{array}$ & - \\
\hline $\begin{array}{l}\text { Giannella, } 2020 \\
\text { (the present report) }\end{array}$ & 45 & 20 & $\mathrm{CT}+\mathrm{RT}$ & $\mathrm{CCC}$ & $2 \mathrm{CS}$ & Death after 7 months \\
\hline
\end{tabular}

CT, Chemotherapy; RT, radiotherapy; CCC, clear cell carcinoma; CS, cesarean section.

\section{Discussion}

CCC of the abdominal wall is a rare and aggressive carcinoma that is often diagnosed as a metastatic and unresectable disease (9). The majority of cases occur in surgical scar endometriosis after the cesarean section (9). Despite its rarity, an increased number of reported cases have been noted in the last few years (10). This might be due to the increased cesarean section and conservative uterine surgery rates that have been documented worldwide (10).
The diagnostic criteria for the malignant transformation of AWE are not well defined. In 1925, Sampson first described the malignant transformation of ectopic endometrial tissue and proposed three rules for the diagnosis of this process: i) the endometriosis is closely associated with the neoplasm, ii) histology is compatible with the endometrial origin, and iii) no other primary tumor sites are found (11). However, in Mostoufizadeh's opinion, the simple coexistence of a neoplasm and endometriotic tissue is sufficient to demonstrate the endometriotic origin of the lesion (12). Even 
if the presence of endometriotic tissue is pathognomonic of the disease, according to the literature, the transition zone is detected in only $36-42 \%$ of cases (13).

In our tissue sampling, we did not find endometrial tissue. The absence of endometriosis foci could be explained by a sampling error or a complete replacement of healthy endometrial with massive neoplastic proliferation (10). In this context, an accurate medical history collection becomes crucial. In the present case, a disease linked to ectopic endometrial implants was suspected because the woman's clinical history was characterized by two cesarean sections, highly painful menstrual cycles, and abdominal wall cyclic pain during menses.

In Table I, all reported cases of clear cell carcinoma arising from abdominal wall scar with different treatment methods and follow-up are summarized $(6,10,14-43)$. The literature review showed that a previous cesarean section was present in $91 \%$ of cases. The mean follow-up was approximately 1 year. Also, approximately $26.5 \%$ of women died within 12 months of being diagnosed. The mean age of women was 45.88 years, while the average size of the lesion was $11 \mathrm{~cm}$. Histology revealed the presence of endometriotic tissue in over $60 \%$ of cases.

When feasible, surgical treatment is the gold standard and definitive therapeutic approach in most cases (10). Usually, both ovaries are removed in more than $80 \%$ of cases, and an endometrial biopsy is performed in about $10 \%$ of women (10). Depending on the size of the parietal wall excision, a mesh is often needed (10). According to the literature (Table I), surgical treatment was always performed: an extensive surgery with hysterectomy or salpingo-oophorectomy was conducted in about half of the cases. However, no malignant lesions were observed in uterus and adnexa. This may suggest that CCC arising in the abdominal wall has different clinical evolution in respect to ovarian $\mathrm{CCC}$, and it is likely that there is no link between them. Based on these data, we can assume that the significance of extensive pelvic surgery with hysteroannessiectomy remains unclear when the neoplasia is confined to the abdominal parietal wall. In our case, although surgery was not performed, ultrasound, MRI, and CT evaluation revealed a normal uterus and adnexa. An interesting aspect highlighted by the present case is that neoadjuvant chemotherapy had a higher efficacy on secondary lesions than on the primary lesion. Although there is no literature data to confirm our observation, our finding is consistent with a previous study stating that the best primary lesion treatment includes complete resection of the diseased tissue and adjuvant chemotherapy should also be considered; conversely, neoadjuvant chemotherapy was shown less effective (9). Based on this data, the primary lesion of the abdominal wall should be detected early to be removed surgically in order to obtain a better survival outcome.
Adjuvant chemotherapy and radiotherapy have been reported to improve outcomes, although no consensus is established regarding protocols. Although CCC shows poor chemosensitivity, a combination of carboplatin and paclitaxel has been reported as the preferable regime (39). The prognosis of these patients is quite poor; the median survival time is about 30 months (44).

In our patient, due to the extent of abdominopelvic disease and metastatic localization, surgical treatment was not performed, and only chemotherapy and palliative radiation therapy were administered.

\section{Conclusion}

CCC of the abdominal wall is a rare condition with just over thirty cases reported in the literature. Middle-aged women showing an abdominal wall mass in correspondence with a surgical scar from a previous cesarean section must be promptly investigated. Treatment options usually include surgery and chemotherapy with poor results. No published treatment guidelines are available because of its rarity. Given the low chemosensitivity, early surgery should be the treatment of choice for the primary lesion. From a preventive point of view, it must be emphasized that every gynecological surgery should always pay close attention not to leave visible tissue remnants on the abdominal wall.

\section{Conflicts of Interest}

There are no conflicts of interest.

\section{Authors' Contributions}

LG, MS and AC reviewed literature data and prepared the draft of the manuscript; EM, JDG, GDC and FS reviewed literature data; $\mathrm{EM}, \mathrm{RB}$ planned the therapeutic regimens; $\mathrm{AC}$ and $\mathrm{RB}$ reviewed the final version of the manuscript. All Authors read and approved the final version of the manuscript.

\section{Informed Consent}

Standard written informed consent was obtained from the patient for the use of data, pictures and videos for teaching, research purposes, and publication.

\section{References}

1 Johnson NP and Hummelshoj L: World Endometriosis Society Montpellier Consortium. Consensus on current management of endometriosis. Hum Reprod 28(6): 1552-1568, 2013. PMID: 23528916. DOI: $10.1093 /$ humrep/det050

2 Giannella L, La Marca A, Ternelli G and Menozzi G: Rectus abdominis muscle endometriosis: case report and review of the literature. J Obstet Gynaecol Res 36(4): 902-906, 2010. PMID: 20666967. DOI: 10.1111/j.1447-0756.2010.01236.x 
3 Ozel L, Sagiroglu J, Unal A, Unal E, Gunes P, Baskent E, Aka $\mathrm{N}$, Titiz MI and Tufekci EC: Abdominal wall endometriosis in the cesarean section surgical scar: A potential diagnostic pitfall. J Obstet Gynaecol Res 38(3): 526-530, 2012. PMID: 22381104. DOI: $10.1111 / \mathrm{j} .1447-0756.2011 .01739 . x$

4 Francica G: Reliable clinical and sonographic findings in the diagnosis of abdominal wall endometriosis near cesarean section scar. World J Radiol 4(4): 135-140, 2012. PMID: 22590667. DOI: $10.4329 /$ wjr.v4.i4.135

5 Kocakusak A, Arpinar E, Arikan S, Demirbag N, Tarlaci A, Kabaca C: Abdominal wall endometriosis: A diagnostic dilemma for surgeons. Med Princ Pract 14(6): 434-437, 2005. PMID: 16220019. DOI: $10.1159 / 000088118$.

6 Bats AS, Zafrani Y, Pautier P, Duvillard P and Morice P: Malignant transformation of abdominal wall endometriosis to clear cell carcinoma: case report and review of the literature. Fertil Steril 90(4): 1197.e13-16, 2008. PMID: 18082734. DOI: 10.1016/j.fertnstert.2007.08.080

7 Krawczyk N, Banys-Paluchowski M, Schmidt D, Ulrich U and Fehm T: Endometriosis-associated malignancy. Geburtshilfe Frauenheilkd 76(2): 176-181, 2016. PMID: 26941451. DOI: $10.1055 / \mathrm{s}-0035-1558239$

8 Van Gorp T, Amant F, Neven P, Vergote I and Moerman P: Endometriosis and the development of malignant tumours of the pelvis. A review of literature. Best Pract Res Clin Obstet Gynaecol 18(2): 349-371, 2004. PMID: 15157647. DOI: 10.1016/j.bpobgyn.2003.03.001

9 Lai YL, Hsu HC, Kuo KT, Chen YL, Chen CA and Cheng WF: Clear cell carcinoma of the abdominal wall as a rare complication of general obstetric and gynecologic surgeries: 15 years of experience at a large academic institution. Int J Environ Res Public Health 16(4): 552, 2019. PMID: 30769847. DOI: $10.3390 /$ ijerph 16040552

10 Ferrandina G, Palluzzi E, Fanfani F, Gentileschi S, Valentini AL, Mattoli MV, Pennacchia I, Scambia G and Zannoni G: Endometriosis-associated clear cell carcinoma arising in caesarean section scar: a case report and review of the literature. World J Surg Oncol 14(1): 300, 2016. PMID: 27912770. DOI: 10.1186/s12957-016-1054-7

11 Sampson JA: Endometrial carcinoma of the ovary arising in endometrial tissue in that organ. Arch Surg 10: 1-72, 1925. DOI: 10.1001/archsurg.1925.01120100007001

12 Mostoufizadeh M and Scully RE: Malignant tumors arising in endometriosis. Clin Obstet Gynecol 23: 951-963, 1980. PMID: 7418292.

13 Benoit L, Arnould L, Cheynel N, Diane B, Causeret S, Machado A, Collin F, Fraisse J and Cuisenier J: Malignant extraovarian endometriosis: a review. Eur J Surg Oncol 32(1): 6-11, 2006. PMID: 16289714. DOI: 10.1016/j.ejso.2005.08.011

14 Schnieber D and Wagner-Koib D: Malignant transformation of extragenital endometriosis. Geburtshilfe Frauenheilkd 46: 658659, 1986. PMID: 3770417. DOI: 10.1055/s-2008-1036277

15 Hitti IF, Glasberg SS and Lubicz S: Clear cell carcinoma arising in extraovarian endometriosis; report of three cases and review of the literature. Gynecol Oncol 17: 520-521, 1996. PMID: 2258077. DOI: 10.1016/0090-8258(90)90259-n

16 Miller DM, Schouls JJ and Ehelen TG: Clear cell carcinoma arising in extragonadal endometriosis in a cesarean section scar during pregnancy. Gynecol Oncol 70: 127-130, 1998. PMID: 9698489. DOI: 10.1006/gyno.1998.4989
17 Park SW, Hong SM, Wu HG and Ha SW: Clear cell carcinoma arising in a cesarean section scar endometriosis: a case report. J Korean Med Sci 14(2): 217-219, 1999. PMID: 10331572. DOI: 10.3346/jkms.1999.14.2.217

18 Ishida GM, Motoyama T, Watanabe T and Emura I: Clear cell carcinoma arising in a cesarean section scar. Report of a case with fine needle aspiration cytology. Acta Cytol 47(6): 10951098, 2003. PMID: 14674088. DOI: 10.1159/000326655

19 Sergent F, Baron M, Le Cornee JB, Scotte M, Mace P and Marpeau L: Malignant transformation of abdominal wall endometriosis: a new case report. J Gynecol Obstet Biol Reprod 35: 186-190, 2006. PMID: 16575366. DOI: 10.1016/s03682315(06)76394-3

20 Alberto VO, Lynch M, Labbei FN and Jeffers M: Primary abdominal wall clear cell carcinoma arising in a Caesarean section scar endometriosis. Ir J Med Sci 175(1): 69-71, 2006. PMID: 16615235. DOI: 10.1007/bf03169006

21 Razzouk K, Roman H, Chanavaz-Lacheray I, Scotté M, Verspyck E and Marpeau L: Mixed clear cell and endometrioid carcinoma arising in parietal endometriosis. Gynecol Obstet Invest 63(3): 140-142, 2007. PMID: 17057400. DOI: 10.1159/ 000096437

22 Harry VN, Shanbhag S, Lyall M, Narayansingh GV and Parkin DE: Isolated clear cell adenocarcinoma in scar endometriosis mimicking an incisional hernia. Obstet Gynecol 110(2 Pt 2): 469-471, 2007. PMID: 17666631. DOI: 10.1097/01.AOG. $0000260393.46154 .5 \mathrm{f}$

23 Rust MM, Susa J, Naylor R and Cavuoti D: Clear cell carcinoma in a background of endometriosis. Case report of a finding in a midline abdominal scar 5 years after a total abdominal hysterectomy. Acta Cytol 52(4): 475-480, 2008. PMID: 18702369. DOI: $10.1159 / 000325557$

24 Achach T, Rammeh S, Trabelsi A, Ltaief R, Ben Abdelkrim S, Mokni M and Korbi S: Clear cell adenocarcinoma arising from abdominal wall endometriosis. J Oncol 2008: 478325, 2008. PMID: 19266089 . DOI: $10.1155 / 2008 / 478325$

25 Williams C, Petignat P, Belisle A and Drouin P: Primary abdominal wall clear cell carcinoma: case report and review of literature. Anticancer Res 29(5): 1591-1593, 2009. PMID: 19443371.

26 Matsuo K, Alonsozana EL, Eno ML, Rosenshein NB and Im DD: Primary peritoneal clear cell adenocarcinoma arising in previous abdominal scar for endometriosis surgery. Arch Gynecol Obstet 280(4): 637-641, 2009. PMID: 19219617. DOI: 10.1007/s00404-009-0962-y

27 Bourdel N, Durand M, Gimbergues P, Dauplat J and Canis M: Exclusive nodal recurrence after treatment of degenerated parietal endometriosis. Fertil Steril 93(6): 2074.e1-6, 2010. PMID: 20045513. DOI: 10.1016/j.fertnstert.2009.11.004

28 Yan Y, Li L, Guo J, Zheng Y and Liu Q: Malignant transformation of an endometriotic lesion derived from an abdominal wall scar. Int J Gynaecol Obstet 115(2): 202-203, 2011. PMID: 21872248. DOI: 10.1016/j.ijgo.2011.06.018

29 Li X, Yang J, Cao D, Lang J, Chen J and Shen K: Clear-cell carcinoma of the abdominal wall after cesarean delivery. Obstet Gynecol 120(2 Pt 2): 445-448, 2012. PMID: 22825261. DOI: 10.1097/AOG.0b013e31824da6fe

30 Mert I, Semaan A, Kim S, Ali-Fehmi R and Morris RT: Clear cell carcinoma arising in the abdominal wall: two case reports and literature review. AJOG 207(2): e7-9, 2012. PMID: 22840730. DOI: 10.1016/j.ajog.2012.05.029 
31 Shalin SC, Haws AL, Carter DG and Zarrin-Khamel N: Clear cell adenocarcinoma arising from endometriosis in abdominal wall cesarean section scar: a case report and review of the literature. J Cutan Pathol 39(11): 1035-1041, 2012. PMID: 22882475. DOI: 10.1111/j.1600-0560.2012.01982.x

32 Ijichi S, Mori T, Suganuma I, Yamamoto T, Matsushima H, Ito F, Akiyama M, Kusuki I and Kitawaki J: Clear cell carcinoma arising from cesarean section scar endometriosis: case report and review of the literature. Case Rep Obstet Gynecol 2014: 642483, 2014. PMID: 25530894. DOI: 10.1155/2014/642483

33 Aust S, Tiringer D, Grimm C, Stani J and Langer M: Therapy of a clear cell adenocarcinoma of unknown primary arising in the abdominal wall after caesarean section and after hysterectomy. Wien Klin Wochenschr 127(1-2): 62-64, 2015. PMID: 25301100. DOI: 10.1007/s00508-014-0619-0

34 Heller DS, Houck K, Lee ES and Granick MS: Clear cell adenocarcinoma of the abdominal wall: a case report. J Reprod Med 59(5-6): 330-332, 2014. PMID: 24937978.

35 Liu H, Leng J, Lang J and Cui Q: Clear cell carcinoma arising from abdominal wall endometriosis: a unique case with bladder and lymph node metastasis. World J Surg Oncol 12: 51, 2014. PMID: 24597651. DOI: 10.1186/1477-7819-12-51

36 Ruiz MP, Wallace DL and Connell MT: Transformation of abdominal wall endometriosis to clear cell carcinoma. Case Rep Obstet Gynecol 2015: 123740, 2015. PMID: 26457213. DOI: $10.1155 / 2015 / 123740$

37 Sosa-Durán EE, Aboharp-Hasan Z, Mendoza-Morales RC, García-Rodríguez FM, Jiménez-Villanueva $X$ and PeñaveraHernández JR: Clear cell adenocarcinoma arising from abdominal wall endometriosis. Cir Cir 84(3): 245-249, 2016. PMID: 26272425. DOI: 10.1016/j.circir.2015.06.024

38 Graur F, Mois E, Elisei R, Furcea L, Dragota M, Zaharie T and Al Hajjar N: Malignant endometriosis of the abdominal wall. Ann Ital Chir 6: pii: S2239253X17026895, 2017. PMID: 28430112 .
39 Marques C, Silva TS and Dias MF: Clear cell carcinoma arising from abdominal wall endometriosis - Brief report and review of the literature. Gynecol Oncol Rep 20: 78-80, 2017. PMID: 28367489. DOI: $10.1016 /$ j.gore.2017.03.008

40 Gentile JKA, Migliore R, Kistenmacker FJN, Oliveira MM, Garcia RB, Bin FC, Souza PMSB and Assef JC: Malignant transformation of abdominal wall endometriosis to clear cell carcinoma: case report. Sao Paulo Med J 136(6): 586590, 2018. PMID: 29116312. DOI: 10.1590/1516-3180.2017. 0103300417

41 Rivera Rolon MDM, Allen D, Richardson G and Clement C: Abdominal wall clear cell carcinoma: Case report of a rare event with potential diagnostic difficulties. Case Rep Pathol 2019: 16957342019, 2019. PMID: 31396428. DOI: 10.1155/2019/ 1695734

42 Lopes A, Anton C, Slomovitz BM, Accardo de Mattos L and Marino Carvalho F: Clear cell carcinoma arising from abdominal wall endometrioma after cesarean section. Int $\mathbf{J}$ Gynecol Cancer 29(8): 1332-1335, 2019. PMID: 31451559. DOI: $10.1136 /$ ijgc-2019-000808

43 Behbehani S, Magtibay $\mathrm{P}$, Chen $\mathrm{L}$ and Wasson M: Clear cell carcinoma of the anterior abdominal wall secondary to iatrogenic endometriosis. J Minim Invasive Gynecol pii: S1553-4650(19)31364-0, 2019. PMID: 31899266. DOI: 10.1016/j.jmig.2019.12.016

44 Taburiaux L, Pluchino N, Petignat $\mathrm{P}$ and Wenger JM: Endometriosis-associated abdominal wall cancer: a poor prognosis? Int J Gynecol Cancer 25(9): 1633-1638, 2015. PMID: 26448542. DOI: $10.1097 /$ IGC.0000000000000556

Received March 28, 2020

Revised April 25, 2020

Accepted April 28, 2020 